\title{
Calibration of HEC-RAS Model for One Dimensional Steady Flow Analysis-A Case of Senegal River Estuary Downstream Diama Dam
}

\author{
Raymond Diedhiou' ${ }^{1}$, Soussou Sambou${ }^{1}$, Seidou Kane ${ }^{1}$, Issa Leye ${ }^{1}$, Samo Diatta ${ }^{2}$, \\ Mousse Landing Sane', Didier Maria Ndione ${ }^{1}$ \\ ${ }^{1}$ Hydraulic and Fluids Mechanics Laboratory (HFML), Department of Physics, Faculty of Sciences and Technology, \\ Cheikh Anta Diop University (UCAD), Dakar-Fann, Senegal \\ ${ }^{2}$ Polytechnic High School of Thies, Thies, Senegal \\ Email: raydiedhiou@yahoo.fr
}

How to cite this paper: Diedhiou, R., Sambou, S., Kane, S., Leye, I., Diatta, S., Sane, M.L. and Ndione, D.M. (2020) Calibration of HEC-RAS Model for One Dimensional Steady Flow Analysis-A Case of Senegal River Estuary Downstream Diama Dam. Open Journal of Modern Hydrology, 10, 45-64.

https://doi.org/10.4236/ojmh.2020.103004

Received: February 9, 2020

Accepted: June 1, 2020

Published: June 4, 2020

Copyright $\odot 2020$ by author(s) and Scientific Research Publishing Inc. This work is licensed under the Creative Commons Attribution International License (CC BY 4.0).

http://creativecommons.org/licenses/by/4.0/

\begin{abstract}
The Sahelian regions have experienced a drought that has made them vulnerable to hydro-climatic conditions. Strategies have been developed to reduce this vulnerability. The governments of Senegal, Mauritania, Mali and Guinea have created the Organization for the development of the Senegal River (OMVS in french) with the aim of realizing large hydraulic installations. This resulted in the construction of the Diama and Manantali dams in the Senegal River Basin. The first aims to stop the saline intrusion, the second to regulate the flow of the river, to allow the irrigation of agricultural perimeters, and to produce electrical energy. The impoundment of the Diama dam has modified the hydraulic behavior of the estuary. The purpose of this study is to carry out the hydraulic modeling of the estuary of Senegal river downstream of the Diama Dam in transient mode by the HEC-RAS software. Two geometric models were constructed on the basis of a digital terrain model (DTM) using the Arc-GIS and HEC GeoRAS soft wares after processing the collected topographic data. The first geometric model, of which the areas of Senegal river downstream Diama Dam have been represented by cross-section, is one-dimensional. The second one is also one dimensional; in this model, the area of the Senegal River estuary downstream Diama Dam is introduced as water storage zones. The components of these models are the stream sections, lateral links, and storage areas. The flood hydrograph downstream Diama Dam is introduced as conditions at the upstream limits of the models while the tidal is introduced as a downstream condition. After the stability and calibration, the results given by HEC-RAS simulations are the variations of the water levels, the temporal variations of the flow rates for each section, the maximum flow ve-
\end{abstract}


locities and the propagation times of the flood waves. The analysis and comparisons of these results strongly suggest using HEC-RAS issues as a decision-making tool helping to manage floods during times of crisis.

\section{Keywords}

Diama Dam, Estuary, Flood, HEC-RAS, Senegal River

\section{Introduction}

The Senegal River basin experienced hydroclimatic variability that resulted in drought during the 1970s. The resulting is a significant decrease in water of river flows. To this must be added a strong inter-annual irregularity of these flows. This has made the socio-environmental system much more vulnerable. The strategy adopted to reduce this vulnerability was to carry out large-scale hydraulic improvements: these were the Diama dams on the lower Senegal River and Manantali dams on the Bafing River [1]. The completion and launching of the Diama dam led to the artificialization of the estuary and delta of the Senegal River. This led to morphological and sedimentological evolution. The artificial hydrological regime of the Senegal River depends on the rainfall of the high basin and the operation of the Diama and Manantali dams. However, in recent years, the Sahel has experienced wet years that have resulted in increased frequency of flooding. This led to the opening of a load shedding channel $7 \mathrm{~km}$ south of the city of Saint-Louis in 2003. It is therefore necessary to know the cycle of erosion and evolution of sedimentary flows in the delta and estuarine environment [2]. Previous studies have shown that numerical models can be applied to the production of flood risk maps that take into account different flood management strategies or to reconstruct past flood events. Numerical models can use one-dimensional (1D) or two-dimensional (2D) models. Although the 1D modeling approach may be useful in some contexts, mainly for artificial channels, it has limitations when water begins to overflow. And in this case the use of the 2D model is more appropriate [3]. Thus, numerical 2D models have been successfully applied to flood modeling; flow is used as the boundary condition upstream of the main river and a 2D simulation is performed [4]. Nowadays, there are several digital models with different abilities and developers. Some models are free of charge while others require the purchase of a license. Various studies have simulated flooding in floodplains using hydrodynamic models. These models digitally resolve the one- and two-dimensional equations of Saint-Venant. Numerical models have been developed for flood plain delineation and flow simulation. Software such as HEC-RAS (River Analysis System HEC) from the American Corps Hydrological Engineering Center [5], MIKE11 developed at the Danish Hydraulic Institute, Denmark (DHI, 1997), etc., have been widely used for the dynamic simulation of 1D flows in rivers. Recently, GIS has become an essential tool for hydrological modeling 
because of its ability to process large amounts of spatial data and attributes. It has many interesting features such as overlapping and analysis of maps, help to derive and aggregate hydrological parameters from different sources such as soil, vegetation cover and precipitation, if available. The GIS environment allows for the extraction of the necessary hydrological variables from a high-quality numerical elevation model, such as watershed shape, flow directions, slopes, length of roads and delineation of watersheds [3]. With a one-dimensional stable flow model such as HEC-RAS, the water surface profile and water velocities can be well predicted along the River. Tate et al. [6], described in his paper an approach to developing a NTM based on cross-sectional data stored in the US Army Corps of Engineers' hydrological engineering. This approach was applied by linking hydraulic modeling to the Geographic Information System (GIS). Patro et al. [7], successfully performed a 1D and 2D hydrodynamic coupling flood simulation of Mike Flood model in 2001, and thus its model-simulated flood extent was compared to the actual flood area extracted from IRS-ID WIFS imagery. Karamouz M. et al. [8], took a hybrid approach to assessing flood risk using GIS. The results indicated that the methodology developed was effective in modeling and visualizing the spatial extent of different flood scenarios and in identifying areas threatened by flooding in New York City, USA. To predict and control floods, to help develop a flood risk prevention plan, Soualmia and Gharbi [9] used two types of models in the Medjerdawadi watershed (Tunisia). First, hydrological models (HEC-HMS 1D and MARINE 2D) are considered, and second, hydraulic models (HEC-RAS 1D, MIKE 11 and MIKE 21). The results obtained by the various simulations are then compared. Nut and Plermkamon [10] developed a direct treatment approach to the delineation of the floodplain of the river system using GIS and HEC-RAS. Because of the effectiveness of the methods mentioned, the purpose of their research was to analyze the frequency of flooding and the flooded area, as well as creating flood plain maps based on return period changes or flooding in the Lower Phong Basin using HEC-RAS and GIS. Patel et al. [11] demonstrated the utility of the HEC-GeoRAS model for delineating flood plains and determining key hydraulic parameters, as well as the capacity of HEC-RAS to produce hydraulic results in the city of Surat in India. Khattak et al. [12] completed flood zoning maps of the Kabul River in Pakistan by combining HEC-RAS and ArcGIS software.

HEC-RAS, Hydrologic Engineering Centers River Analysis System, is software developed by the Hydrologic Engineering Center (HEC) in California. Its purpose is to do hydraulic modeling to simulate flow in streams and channels. It is capable of modeling hydraulic structures such as culverts, weirs, dikes, flood drains and bridges in a section of the river [5] [13]. It also makes the calculations of the water lines allowing the analysis of the capacity of waterways (risks of overflow, floods) and of the impact of changes in edge conditions (bridges, dams) [14] [15]. It is also used to visualize the cross-sections [16] and to determine the limits of the flood field of reference floods from a topographical study which 
aims to describe the geometry of the terrain for the dimensioning of the protection [17] [18]. However, numerical instability problems may arise during instability analyses, mainly in steep and/or highly dynamic streams. Various tools for analyzing and visualizing temporal and spatial data come from geoinformatics [19] [20]. The software often used in combination with HEC-RAS is ArcGIS [21]. It includes a set of tools and procedures for working with geospatial data. Basic inputs of HEC-RAS include river flow, channel, flood plain geometry and channel strength [12] [22].

This article aims to study the propagation of artificial floods and to analyze the behavior of the Senegal River estuary downstream of the Diama dam using hydrodynamic modeling software HEC-RAS developed by the "Center hydrological engineering, US Army Corps of Engineers". A 1D simulation is carried out in steady state for different flows corresponding to the water releases at the Diama dam. The main output variables of this analysis are the height of the water surface on the cross sections of the river, the flow velocity and the extent of the flood.

\section{Material and Method}

The Senegal River basin is located in the western part of Africa. It extends from latitude $10^{\circ} 20^{\prime} \mathrm{N}$ to latitude $17^{\circ} 00^{\prime} \mathrm{N}$ approximately and is between the meridians $7^{\circ} \mathrm{W}$ and $12^{\circ} 20^{\prime} \mathrm{W}$. It is drained by the $1770 \mathrm{~km}$ long river, from the Fouta Djalon massif in Guinea to the Atlantic Ocean. It is the second longest river in West Africa. Its area is $337,000 \mathrm{~km}^{2}$, including $60,000 \mathrm{~km}^{2}$ in the national territory of Senegal. Most of the Senegal River Basin has a desert sub-Saharan climate, which has been aggravated by more or less long periods of drought in the 1970s. The estuary of the Senegal River is located in the lower delta of the river, bordering the Atlantic Ocean, $250 \mathrm{~km}$ north of Dakar. The estuary faces many environmental problems, the most worrying being coastal erosion and flooding. These last occur during the rainy season, from August to October. They are frequent, recurrent and sometimes very severe, causing a lot of material damage and exceptionally loss of life. Our study area is $50 \mathrm{~km}$ long and lies between the mouth of the Senegal River and the Diama Dam and covers an area of about 10,000 $\mathrm{km}^{2}$ [1] [2] (Figure 1).

\section{Methodology}

GIS provides a wide range of tools for determining areas affected by floods or for predicting areas likely to be flooded due to high river levels. NTMs are increasingly used for visual and mathematical analysis of topography, landscapes and reliefs, as well as for surface process modeling. A DTM is the most common means of displaying topographic information and even allows the modeling of flows through the topography; a control factor in distributed models of relief processes [11]. HEC-RAS uses a number of input parameters for hydraulic analysis of stream geometry and water flow. These parameters are used to establish a 


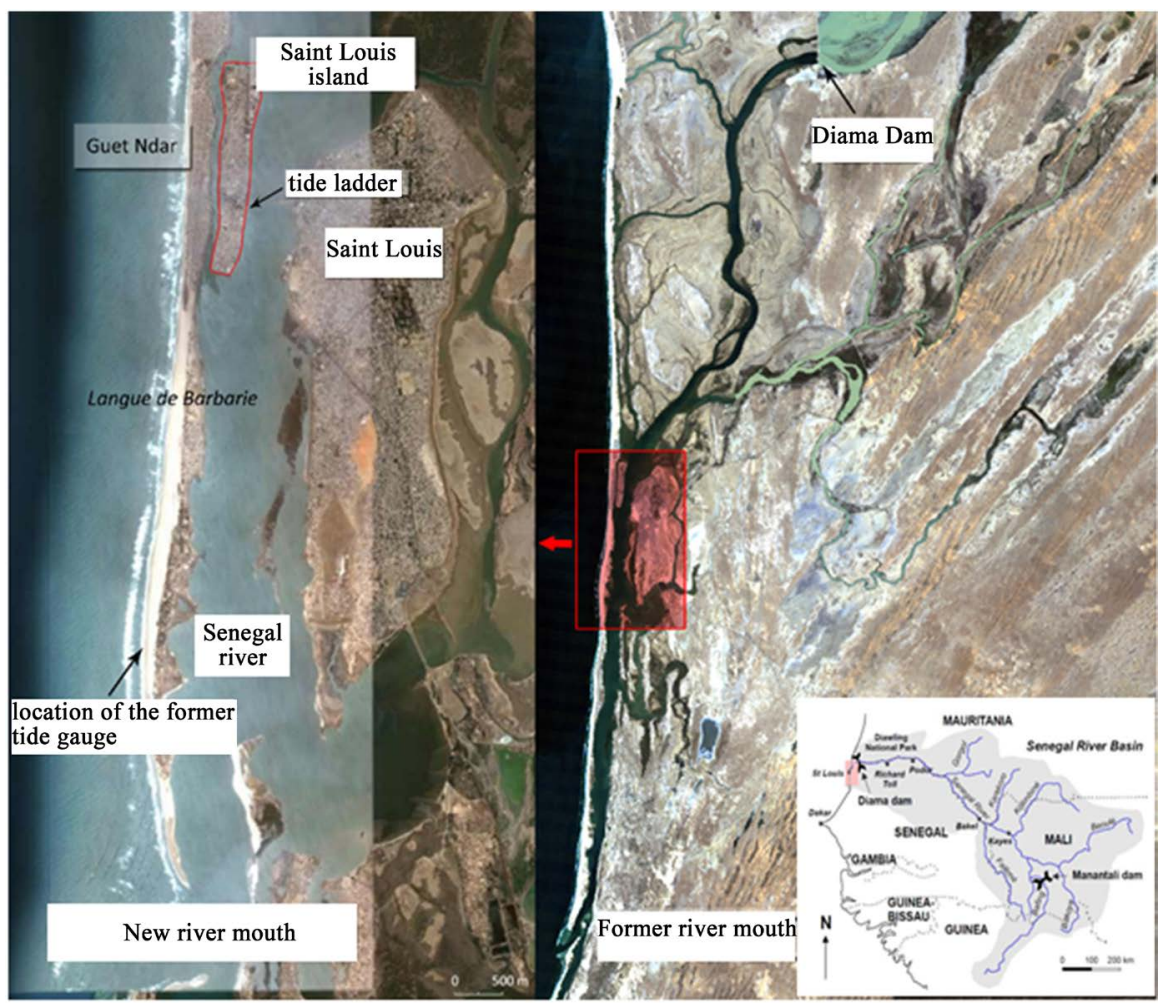

Figure 1. The Senegal river basin and its new mouth.

series of cross sections along the stream [23]. HEC-RAS assumes that the energy load is constant over the entire section and that the velocity vector is perpendicular to the section [14]. In each cross-section, stream bank locations are identified and used to divide into segments of the left-hand channel, the main channel and the right-hand channel. For 1D analysis, the collected data is entered into the HEC-RAS software version 5.0.1. These are sections across the estuary between the Diama Dam and the mouth and bathymetric data. The input parameters to describe the shape, elevation and relative position along the flow are the number of the river station (cross-section), the lateral and altitude coordinates for each terrain point, the location of the left and right bank stations, the distances between the left diversion channel, the watercourse axis and the right branch channel of the adjacent cross sections, the Manning roughness coefficient and the contraction and expansion coefficient of the canal [19] [24]. The scope of the study includes 33 cross-sections. In addition, the flow can be changed anywhere in the river system. The discharge must be entered for all profiles. A boundary condition shall be established at the most downstream cross-section for a subcritical flow profile and at the most upstream cross-section for a supercritical flow profile. Based on this input data, HEC-RAS will calculate the section [25] [26]. Since HEC-GeoRAS uses ArcGIS related functions such as Spatial Analyst and 3D Analyst, it must be ensured that these extensions are enabled before loading it [15] [26]. Any hydraulic or hydrological modeling in favor of a GIS environment involves three stages: pre-processing of data, modeling phase 
and post-processing of data. For the pre-treatment, the DEM of the study area was used as the main input to create RAS layers such as flow axis, bank lines, bank stations, trajectory axes, cutting lines XS, etc. The Line tool was used to scan the center lines, left and right banks, flow paths, etc. [18] [27]. The cross sectional cut lines are one of the main HEC-RAS entrances and these cross sections are cut off. Lines are used to extract terrain elevation data to create a soil profile through the channel flow. However, some rules must be observed when scanning cut lines. Before exporting GIS data to HEC-RAS, the Manning value is assigned to different sections based on different types of land use. When the data was exported, he created two files, namely .xml and .sdf, which were used for later operations in HEC-RAS. In order to verify the quality of the data, a cross section editor was used for the individual sections. To set the downstream boundary conditions, the normal depth was set to 0.001 before HEC-RAS was executed. After a successful simulation, the output of HEC-RAS job was exported to ArcMAP for the post-processing to create a delineation of the flood in the study area [11] [12]. Calculations in HEC-RAS model were carried out by solving one dimensional energy equation as written in Equation (1):

$$
Z_{2}+Y_{2}+\frac{\alpha_{2} V_{2}^{2}}{2 g}=Z_{1}+Y_{1}+\frac{\alpha_{1} V_{1}^{2}}{2 g}+h_{e}
$$

where: $Z_{1}$ and $Z_{2}$ are the elevations of the main channel inverts, $Y_{1}$ and $Y_{2}$ are the depths of water at each cross section, $V_{1}$ and $V_{2}$ are the average velocities (total discharge/total flow area), $\alpha_{1}$ and $\alpha_{2}$ are the velocity weight coefficients, $\mathrm{g}$ is the gravitational acceleration, and $h_{e}$ is the energy head loss between the two cross sections.

The energy loss term $h_{e}$ in Equation (1) is composed of friction loss $h_{f}$ and form loss $h_{o}$. Only contraction and expansion losses are considered in the geometric form loss term.

$$
h_{e}=h_{f}+h_{0}
$$

To approximate the transverse distribution of flow of the river is divided into strips having similar hydraulic properties in the direction of flow. Each cross section is subdivided into portions that are referred to as subsections [23]. Friction loss is calculated as shown below:

$$
h_{f}=\left(\frac{Q}{K}\right)^{2}
$$

where:

$$
K=\sum_{j=1}^{J}\left[\frac{1.49}{n_{j}}\right] \frac{\frac{\left(A_{2}+A_{1}\right)}{2}\left[\frac{R_{2}+R_{1}}{2}\right]_{j}^{0.5}}{\left(L_{j}\right)^{0.5}}
$$

$A_{1}, A_{2}$ are the downstream and the upstream area, respectively of the cross sectional flow normal to the flow direction, $J$ is the total number of subsections, 
$L_{j}$ is the length of the $j^{\text {th }}$ strip between subsections, $\mathrm{n}$ is the Manning's roughness coefficient, $Q$ is the water discharge and $R_{1}, R_{2}$ are the downstream and the upstream hydraulic radius.

\section{Other losses:}

Energy losses due to contractions and expansions are computed by the following equation:

$$
h_{0}=C_{L}\left|\frac{\alpha_{2} V_{2}^{2}}{2 g}-\frac{\alpha_{1} V_{1}^{2}}{2 g}\right|
$$

where, $C_{L}$ is the loss coefficient for contraction and expansion. If the quantity within the absolute value notation is negative, flow is contracting, $C_{L}$ is the coefficient for contraction; if is positive, flow is expanding and $C_{L}$ is the coefficient of expansion. In the standard step method for water surface profile computations, calculations proceed from the downstream to upstream based upon the reach's downstream boundary conditions and starting water surface elevation.

Distribution coverage of the weighted distance can be calculated using the following formula:

$$
L=\frac{L_{l o b} \bar{Q}_{l o b}+L_{c h} \bar{Q}_{c h}+L_{r o b} \bar{Q}_{r o b}}{\bar{Q}_{l o b}+\bar{Q}_{c h}+\bar{Q}_{r o b}}
$$

where: $L_{l o b}, L_{c h}, L_{r o b}$ are the lengths specified in the flow direction for the left floodplain, main riverbed and right floodplain, $\bar{Q}_{l o b}, \bar{Q}_{c h}, \bar{Q}_{\text {rob }}$ are the arithmetic average of flows between cross-sections for the left floodplain, main riverbed and right floodplain.

\section{Results and Discussions}

This work combines bathymetric data, hydraulic models and GIS (Geographic Information System) tool for the evaluation of flood flows and the delineation of flood prone areas in the Senegal River estuary downstream of the Diama dam. Hec-Ras software uses 1D Saint-Venant coming equations for shallow waters. These equations are deduced from the Navier-Stokes equations by simplifications related to the fluvial model [15]. The application of the Hec-Ras model for this study is based on three basic steps:

Step 1: creation, using the ArcGIS tool, of the Hec-GeoRAS extension, the digital elevation model (DEM) and the aerial images of Google Earth, the geometric data of the Senegal River estuary with the minor and major sections of the estuary bed and cross sections. Hec-GeoRAS is used as the main tool in ArcMap. In the ArcGIS environment, we used Hec-GeoRAS to digitize various vector elements that will allow Hec-RAS to generate the flood model and represent the results. The digitization of these elements is used in the following phases to realize the potential simulation (Figure 2).

- The main channel;

- The left and right banks;

- Cross sections. 
Step 2: Apply permanent flow modeling with Hec-RAS 5.0.1, which generates an export file for ArcGIS. Hec-Ras is a software independent of ArcMap but complementary to the analysis processes. The calculation of the hydraulic profiles along the bed of the studied section is fundamental to estimate the water levels during exceptional floods. Overflow levels of the river and areas submerged by water will also be known (Figure 3 ). These profiles will also determine drainage areas and those requiring maintenance.

Step 3: Generate water task results: flood surfaces and depth grids. The Hec-Ras modeling allowed to calculate the different flow configurations for the cross sections along the studied section. Water levels, depths, flow velocities and other variables were simulated. The banks, the vegetation, the obstacles and the structures are well identified, which allowed obtain a rather precise geometry of our river. So we created the main axis of the canal.

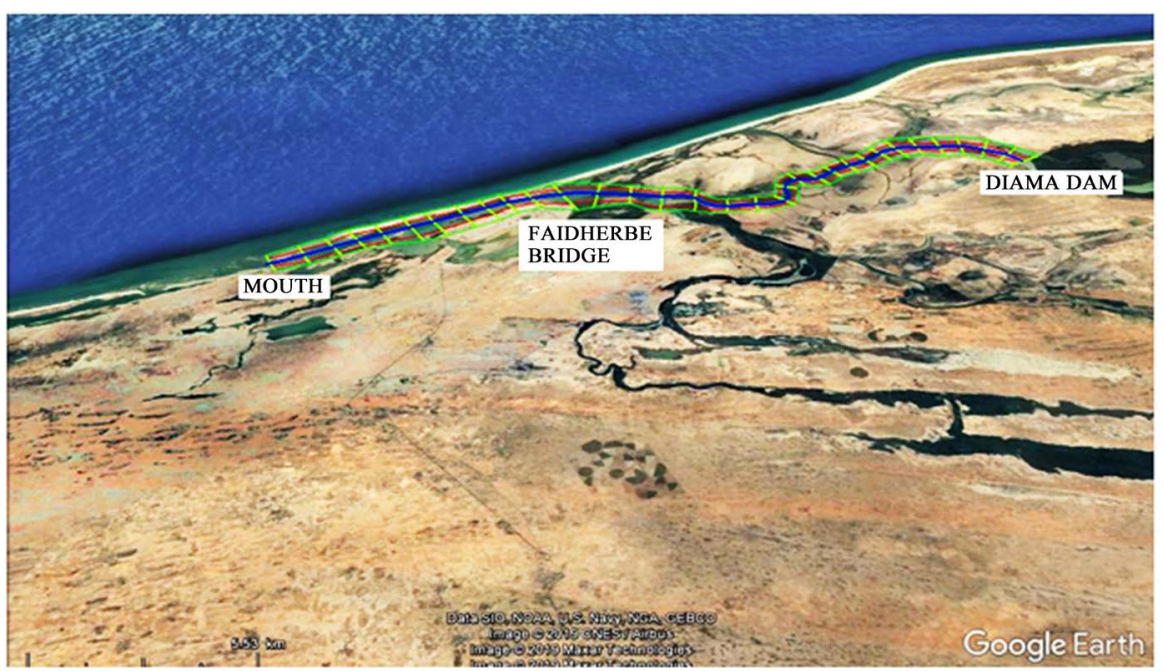

Figure 2. Stream Lines, Flow Paths, Bank Lines and Cross sections (Hec-GeoRas \& Arcmap).

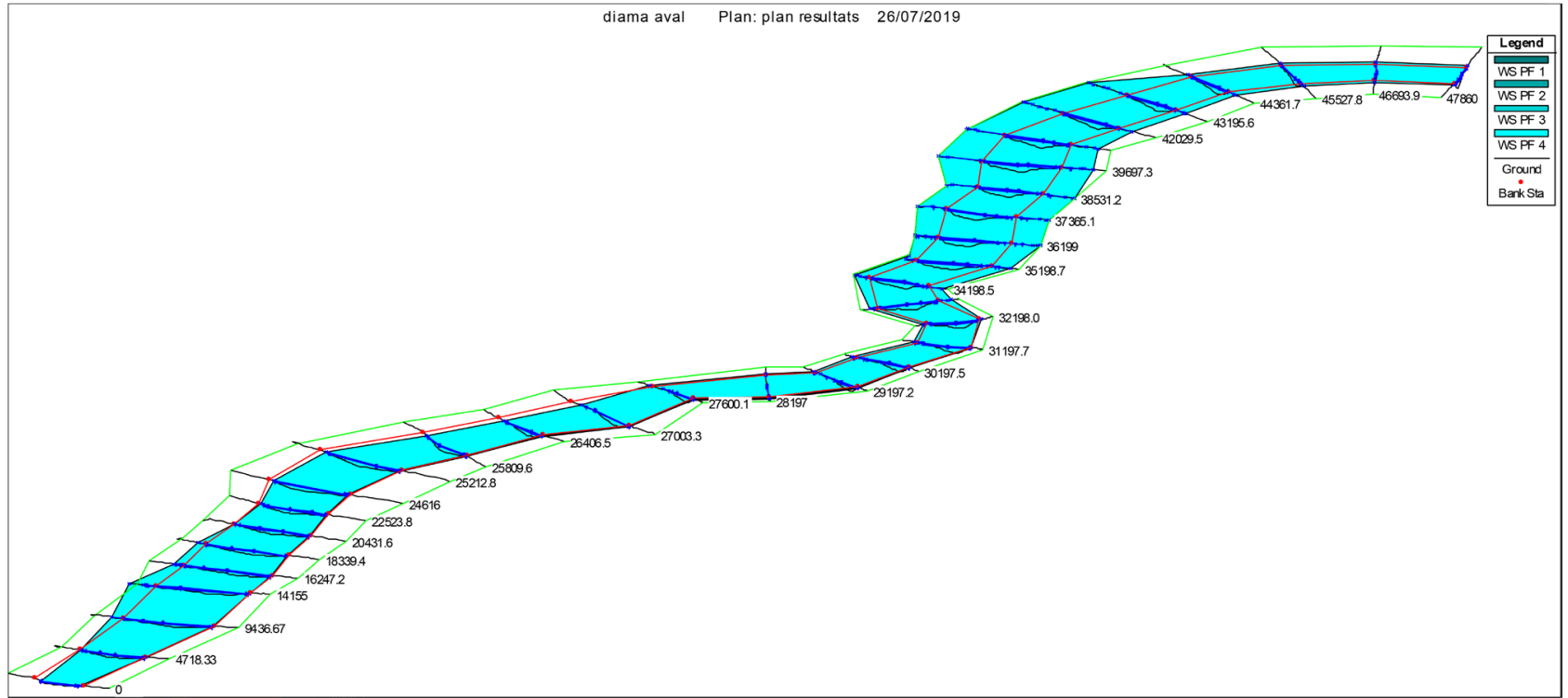

Figure 3. 3D representation under HEC-RAS of the extent of the flood for a flow rate of $2000 \mathrm{~m}^{3} / \mathrm{s}$. 
For a constant flow, we find that the flood covers most of the profiles with large widths downstream. In addition, given the watershed characteristics in terms of geology, geomorphology and vegetation cover, the Manning coefficient retained is 0.03 . This is the value of sandy river beds (devoid of gravel and pebbles) with little aquatic vegetation. In the same way, the estuary is characterized by its mixed regime and its weak slopes. The geometry of the canal is defined by 33 cross sections distributed over the $50 \mathrm{~km}$ of the studied river line (Figure 4 and Figure 5).

The unidimensional hydrological modeling of the flood, in the absence of the tide, of the Senegal river estuary downstream of the Diama dam of the present study was carried out using HEC-RAS version 5.0.1 (Figure 6). For a natural watercourse, flow varies with weather conditions in the watershed and other processes. The results obtained by Hec-Ras modeling are exported to the tool Hec-GeoRAS 5.0.1, which is an extension of Hec-Ras on Arcgis to create the flood zones

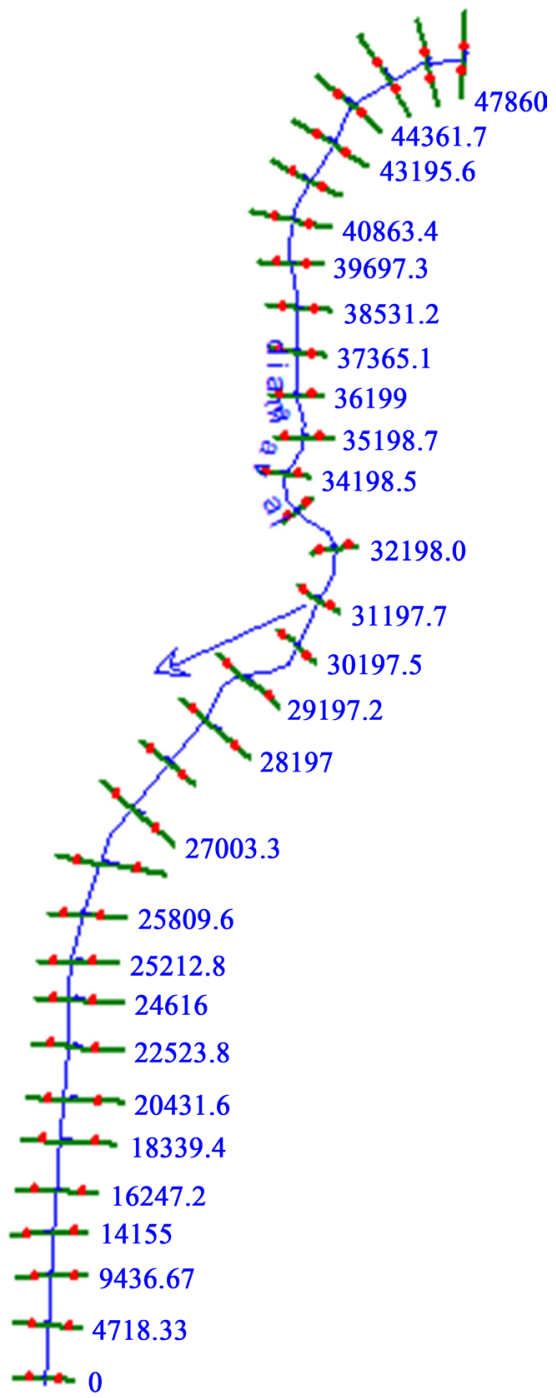

Figure 4. Representation under Hec-Ras of the Senegal River downstream of Diama and corresponding profil. 


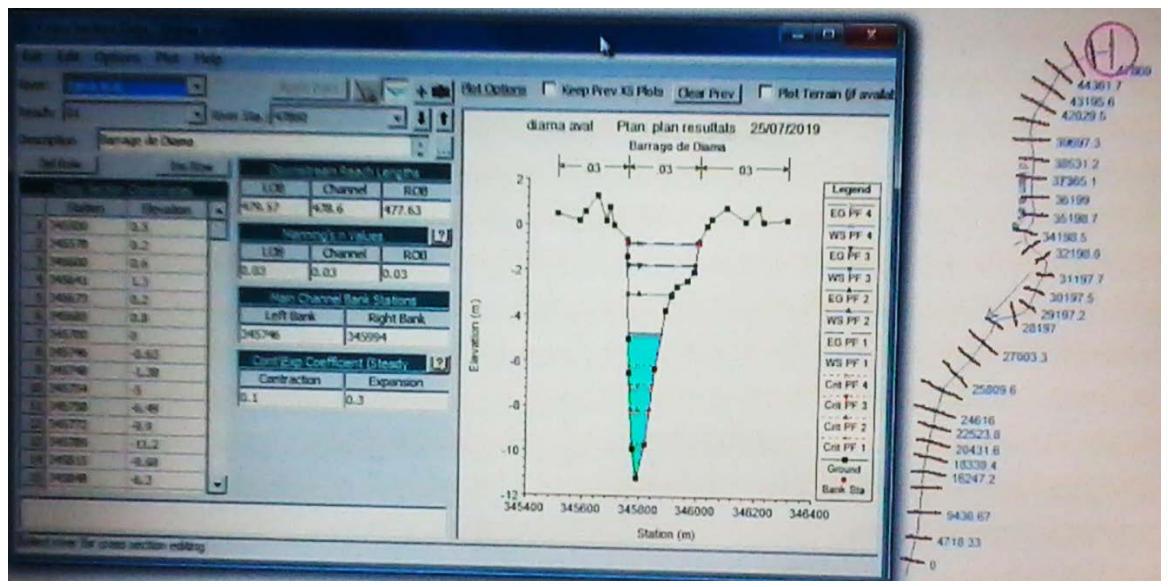

Figure 5. Detail of a cross section-Hec-Ras.

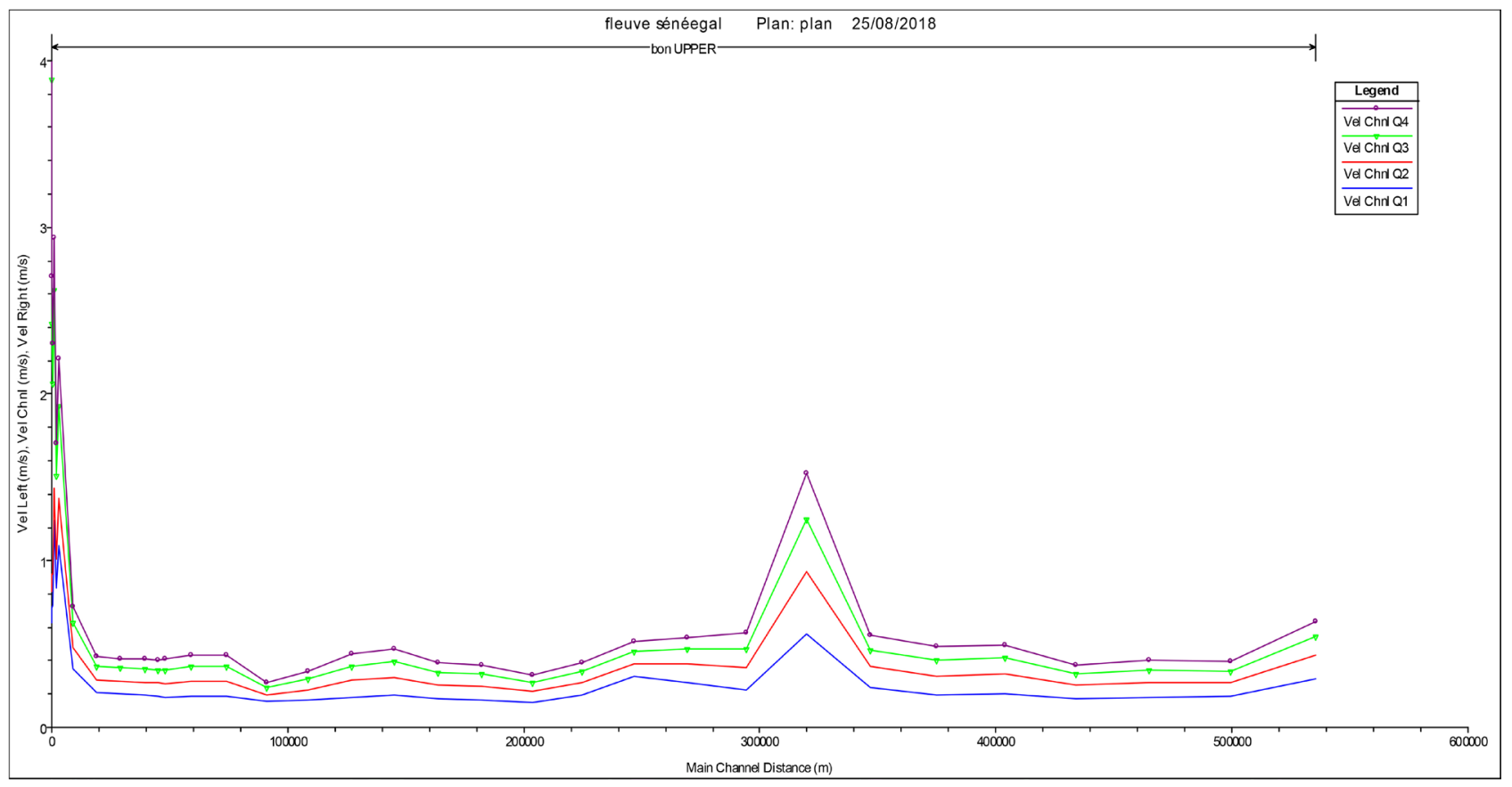

Figure 6. Flow velocity at the channel for flows $\mathrm{Q}_{1}, \mathrm{Q}_{2}, \mathrm{Q}_{3}$ and $\mathrm{Q}_{4}$.

of each profile, which is applied to each flow $\left(Q_{1}, Q_{2}, Q_{3}\right.$ and $\left.Q_{4}\right)$. We zoomed in on three areas: zone A (Figure 7); zone B (Figure 8) and zone C (Figure 9).

The maximum flow observed for the artificial flood (water drop at the Diama Dam) between 2003 and 2011 is of the order of $2000 \mathrm{~m}^{3} / \mathrm{s}$. The test of this modelization is carried out on four stations for four different flow rates: PF1 has a flow of $500 \mathrm{~m}^{3} / \mathrm{s}, \mathrm{PF} 2$ a flow of $1000 \mathrm{~m}^{3} / \mathrm{s}, \mathrm{PF} 3$ a flow of $1500 \mathrm{~m}^{3} / \mathrm{s}$ and PF4 a flow of $2000 \mathrm{~m}^{3} / \mathrm{s}$ (Figure 10). Once the modeling is done, we have access to several results.

We can get information from our simulation on the general profile of the river. The example below, retraces, according to the distance to the starting profile (mouth), the height of water induced by flood flows of 500, 1000, 1500 and 2000 $\mathrm{m}^{3} / \mathrm{s}$ (Figure 10): 
We can also obtain information from our simulation on the water height (W.S.) as a function of flow (Q). We did this simulation on four stations (Figure $11)$.

Our simulation allows to see also the evolution of the flow velocity (Vel) of the flood as a function of the flow (Q) on four stations (Figure 12).

We also obtained the modeling of the water heights (WS) on different sections across the river for different flow rates (Figure 13).
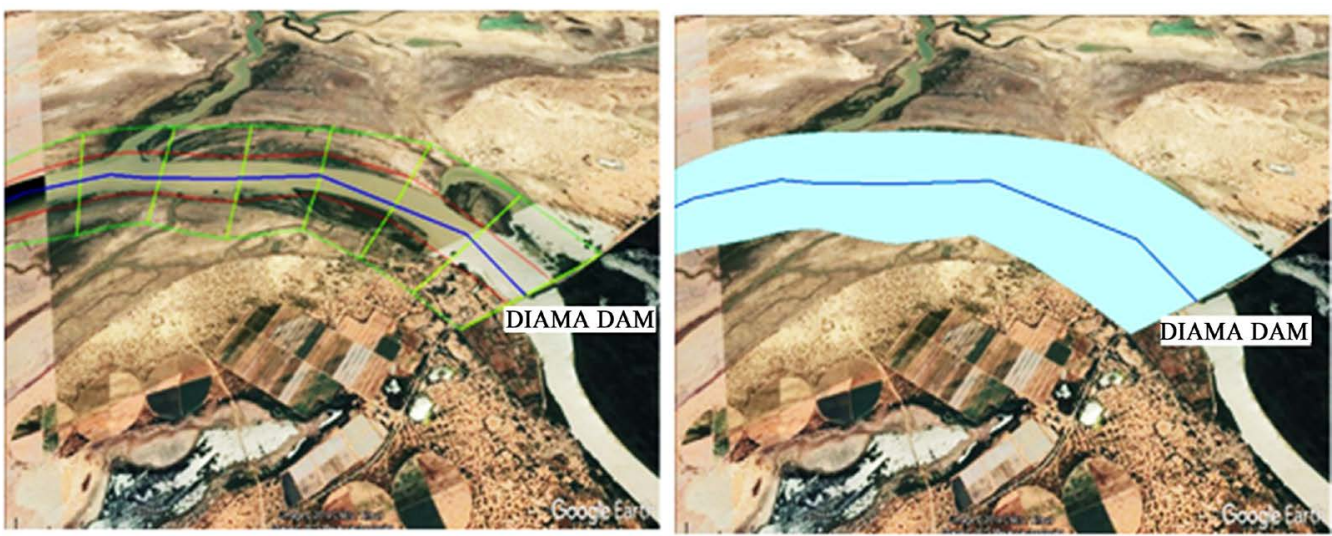

Figure 7. Zone A before simulation (on the left) and after simulation (on the right).
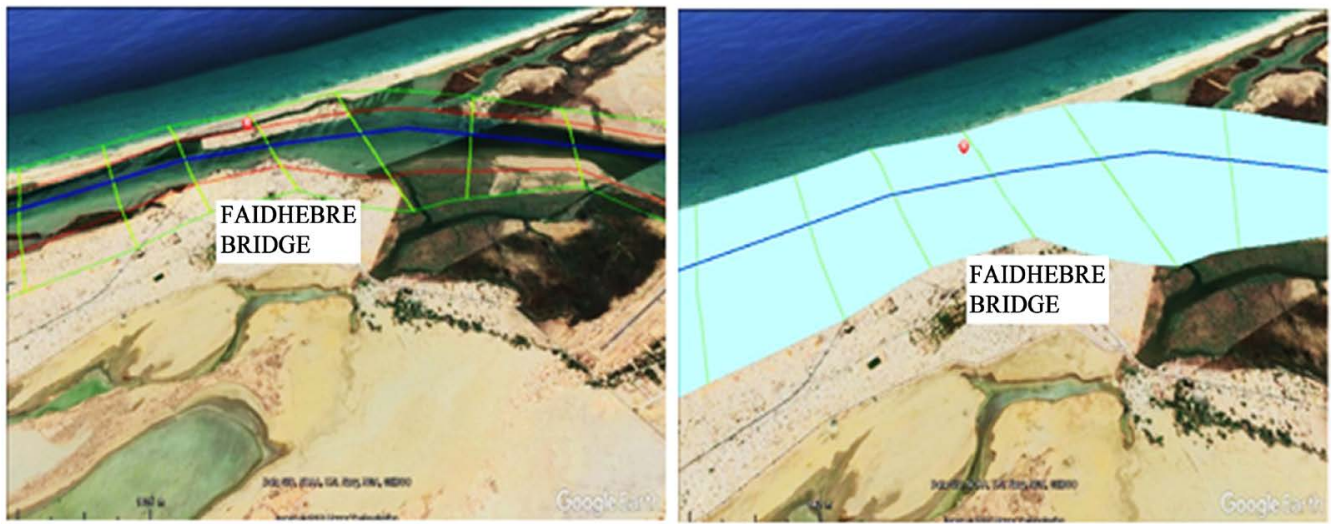

Figure 8. Zone B before simulation (left) and after simulation (right).
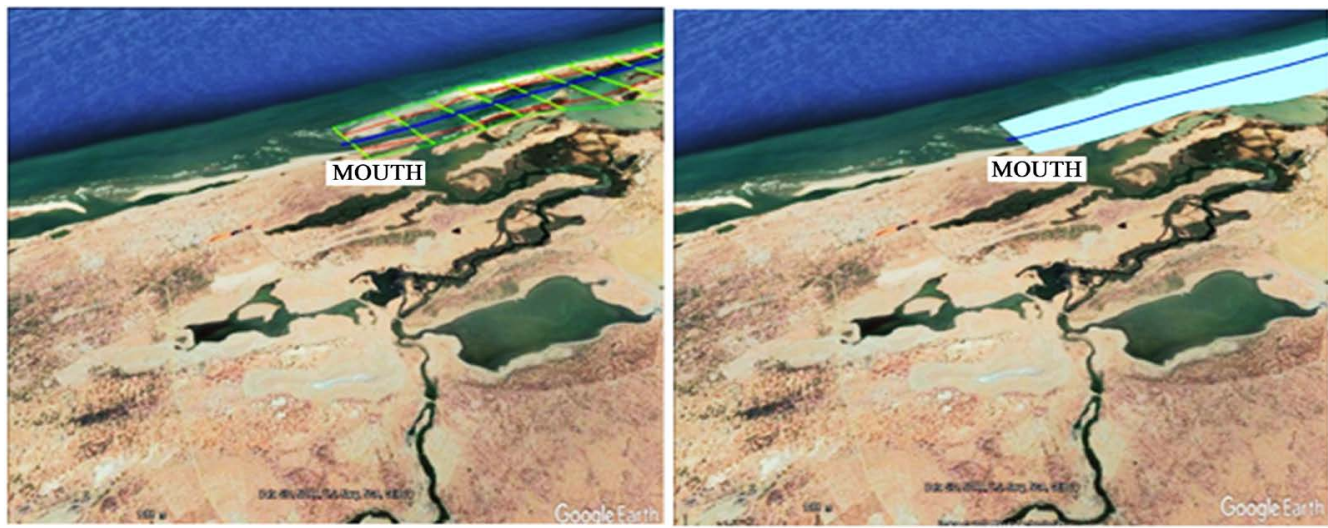

Figure 9. Zone C area before simulation (left) and after simulation (right). 
The bathymetric profiles show irregular bottoms with generally asymmetrical flanks, a phenomenon which is accentuated in the area of the mouth. The profiles are relatively symmetrical and more regular upstream. In the Mermoz area (Figure 13), the channel bottom is narrow with a characteristic V shape; it is quite wide downstream of the dam (usually $>500 \mathrm{~m}$ ).

The maximum depths of the channel are relatively low towards the mouth (about $6 \mathrm{~m}$ ) but become strong upstream where they reach $10 \mathrm{~m}$ at the Faidherbe bridge and $11.80 \mathrm{~m}$ at the immediate downstream of the Diama dam.

In fact, the depths of the channel are very variable over time, in relation to the instability of the bottoms due to the frequent movement of the sand band.

Zone A: This is the area between the Diama Dam and a few kilometers downstream. The artificial flood corresponds to the release of water at this dam. For water releases of flow ranging from $500 \mathrm{~m}^{3} / \mathrm{s}$ to $2000 \mathrm{~m}^{3} / \mathrm{s}$, the simulation shows a sharp increase in the water level (about $2.93 \mathrm{~m}$ ) in this area causing flooding (Figure 7).

The speed chart produced by Hec-Ras for peak flows (500, 1000, 1500 and $2000 \mathrm{~m}^{3} / \mathrm{s}$ ) confirms this result. In the main channel, the velocities are about 0.77 $\mathrm{m} / \mathrm{s}$ and $1.52 \mathrm{~m} / \mathrm{s}$ for the respective flow rates of $500 \mathrm{~m}^{3} / \mathrm{s}$ and $2000 \mathrm{~m}^{3} / \mathrm{s} \mathrm{respec-}$ tively. Also, we visualize a difference of the height of water of $3 \mathrm{~m}$ between these two flows. Flooding in this area occurs whenever the volume of water in the upper parts of the basin exceeds the capacity of the riverbed, the water overflows and flows into the plain (Figure 6 and Figure 12).

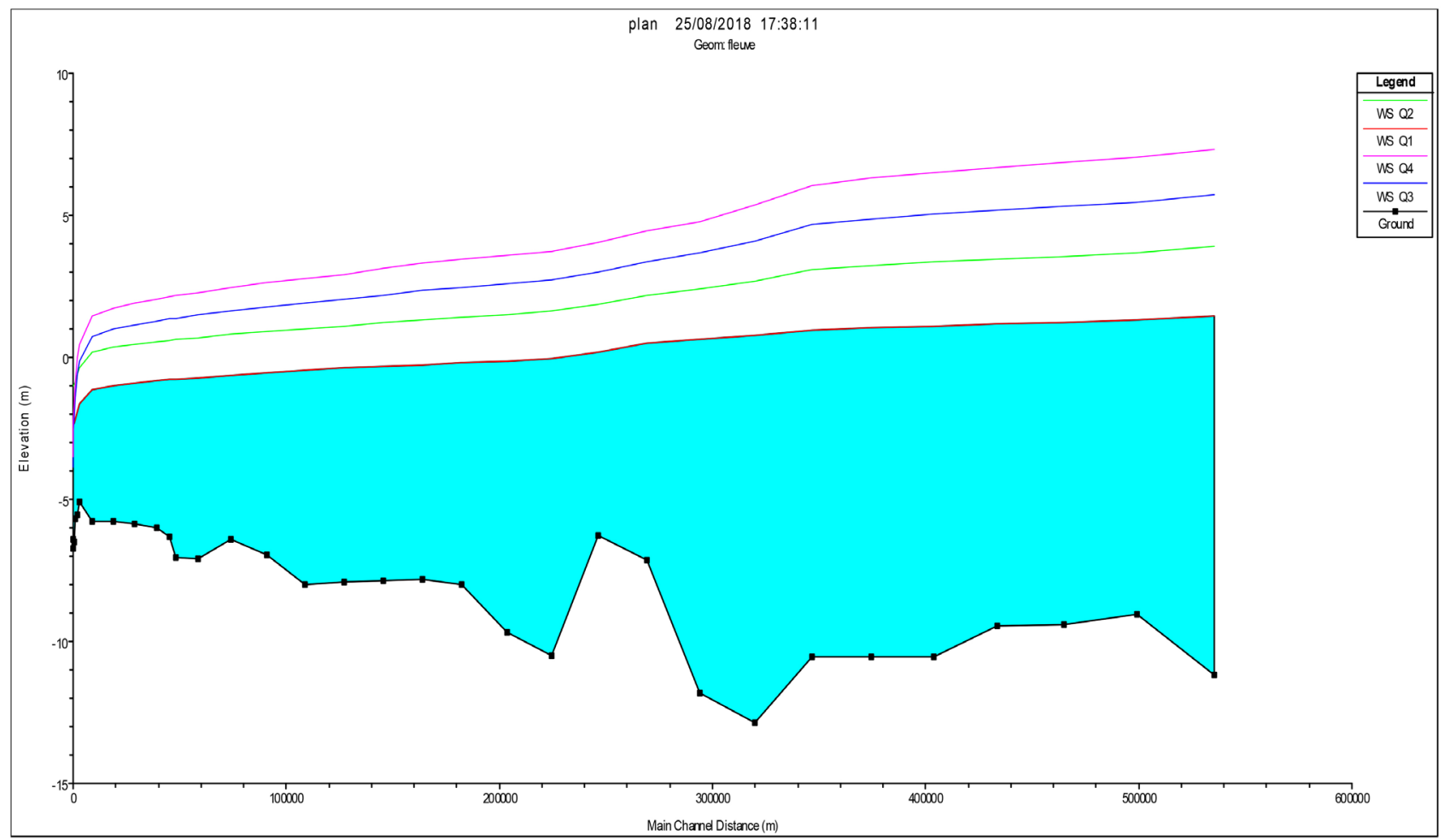

Figure 10. Cutting diagram of the Senegal River downstream of Diama with water heights for floods of 500, 1000, 1500 and 2000 $\mathrm{m}^{3} / \mathrm{s}$. 


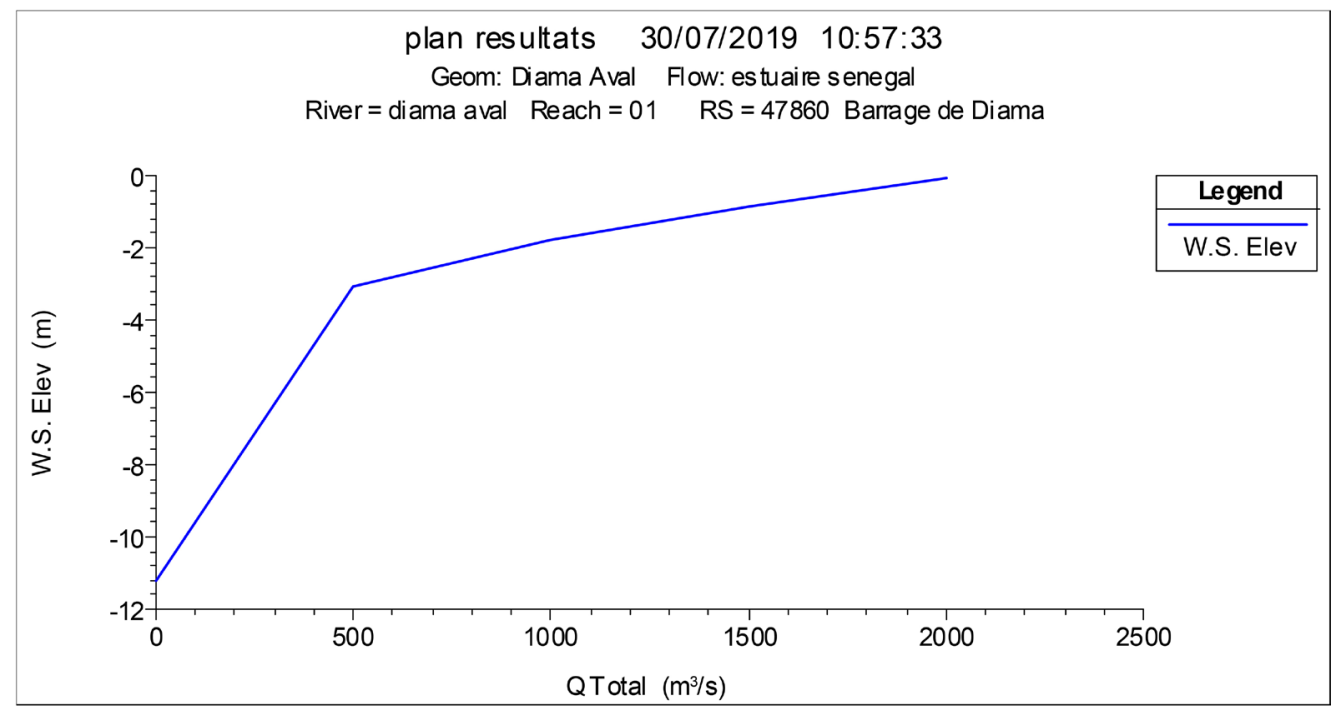

Station 1: Diama Dam

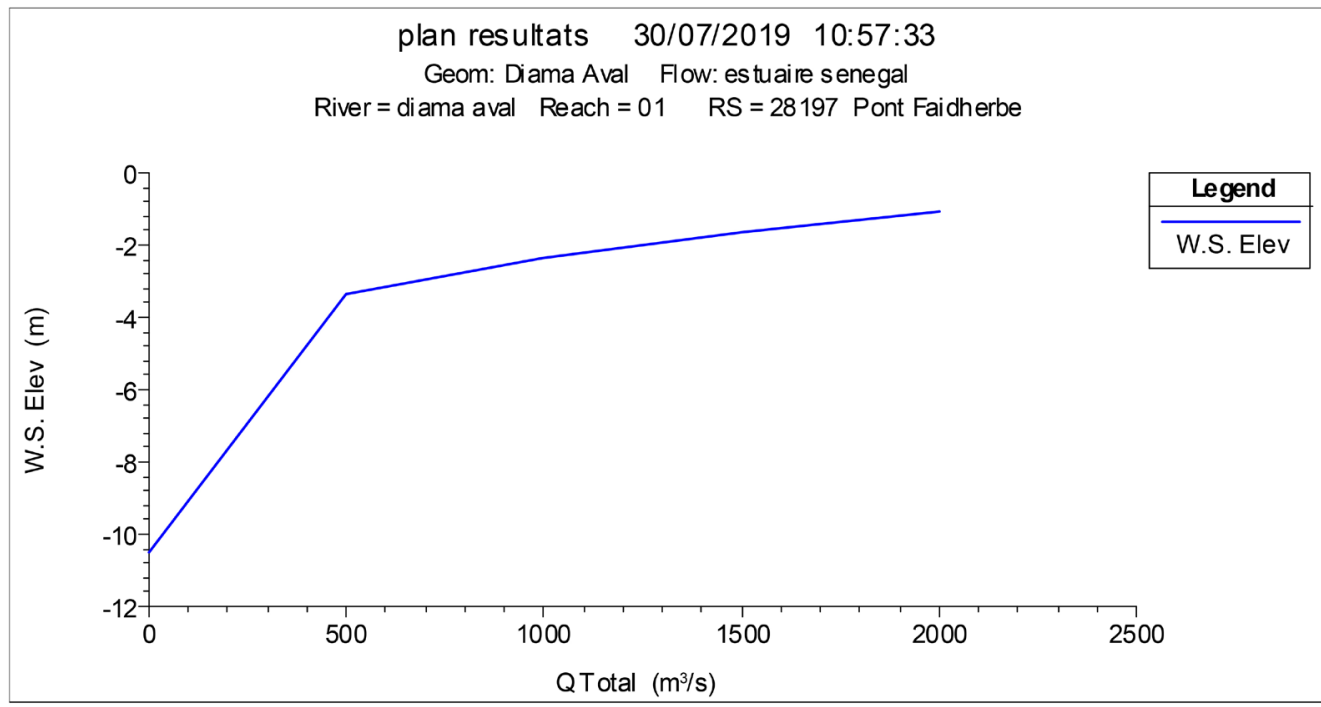

Station 2: Faidherbe Bridge

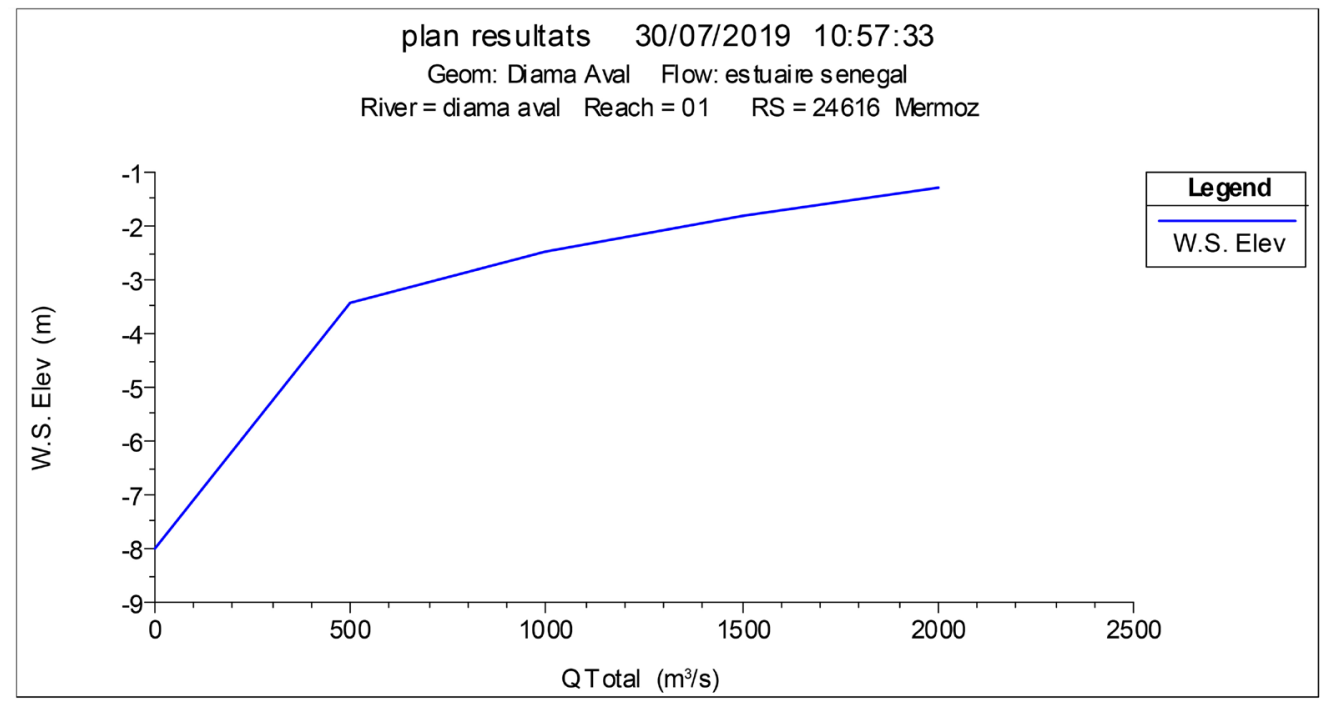

Station 3: Mermoz 


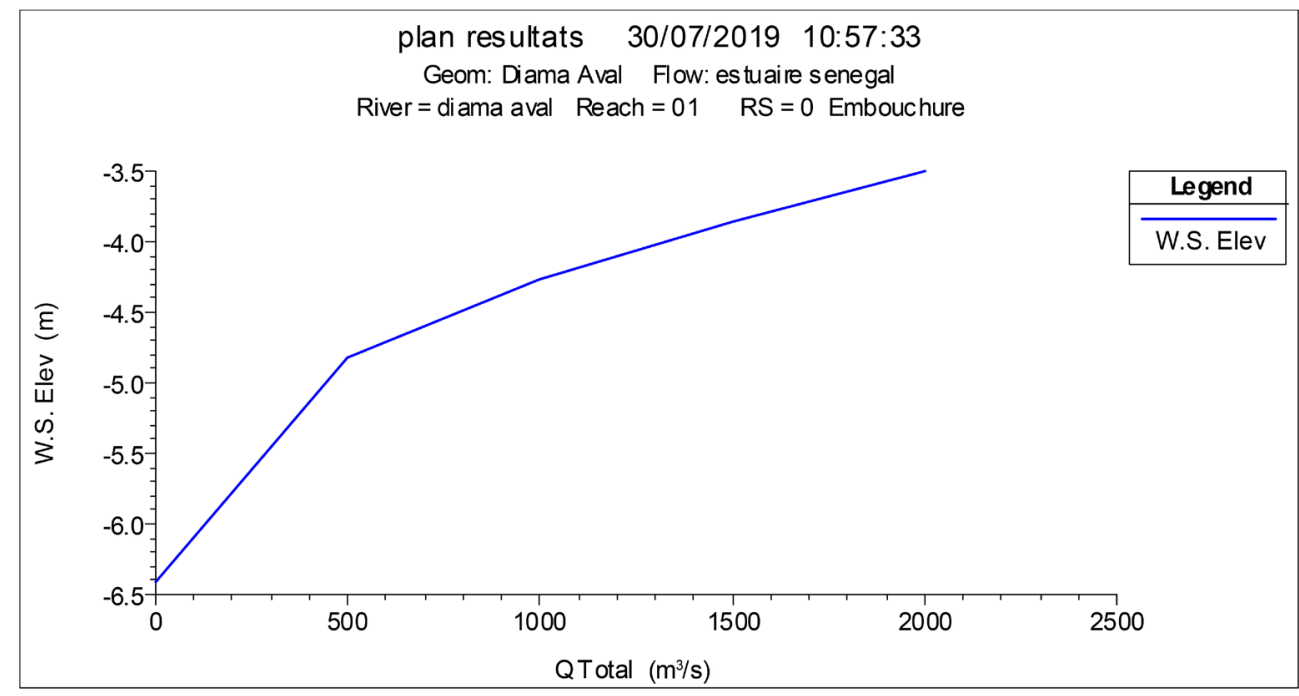

Station 4: Mouth

Figure 11. Variation of the water level according to the flow.

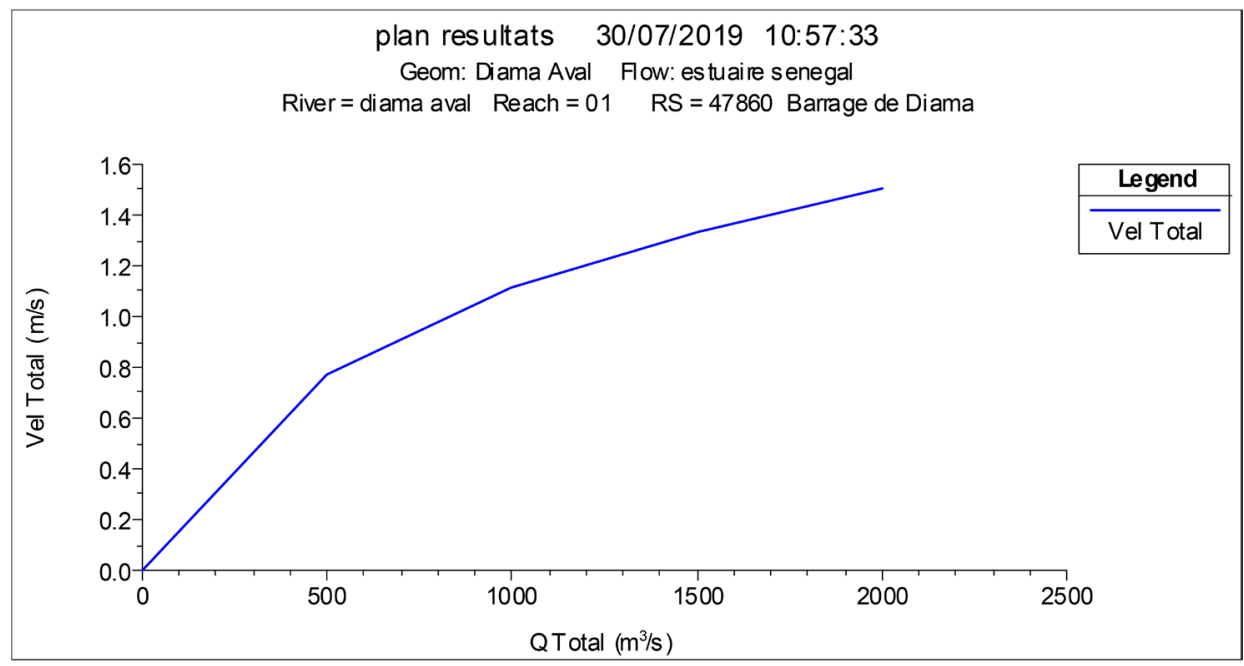

Station 1: Diama Dam

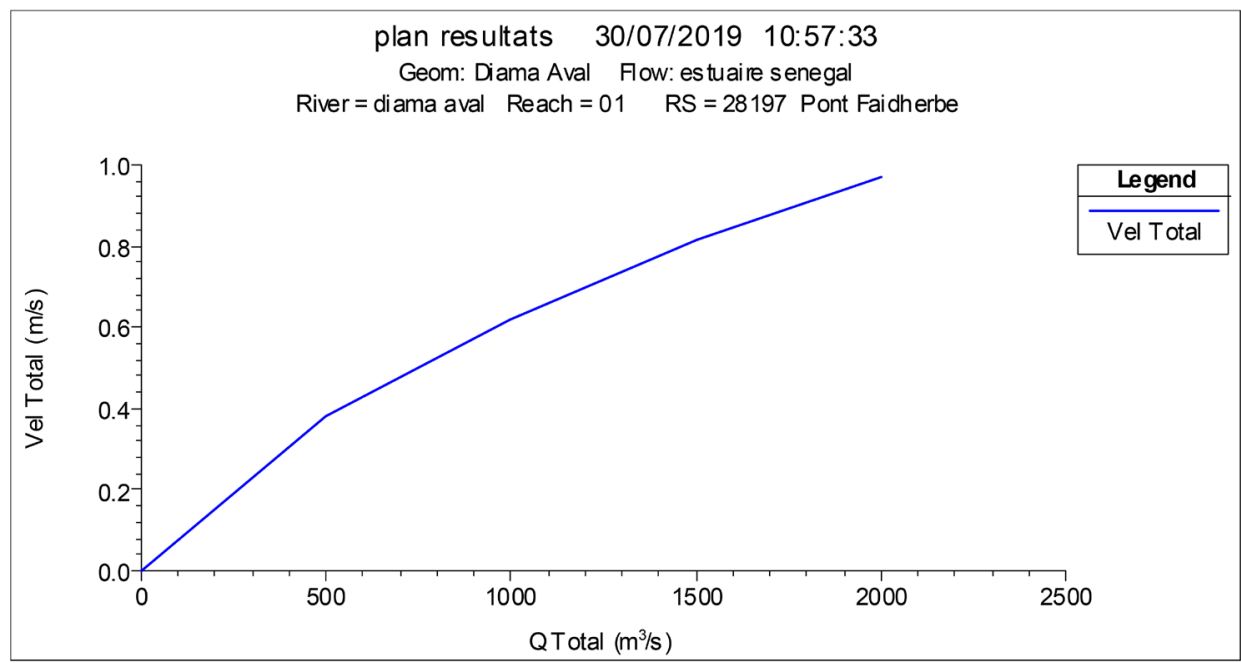

Station 2: Faidherbe Bridge 


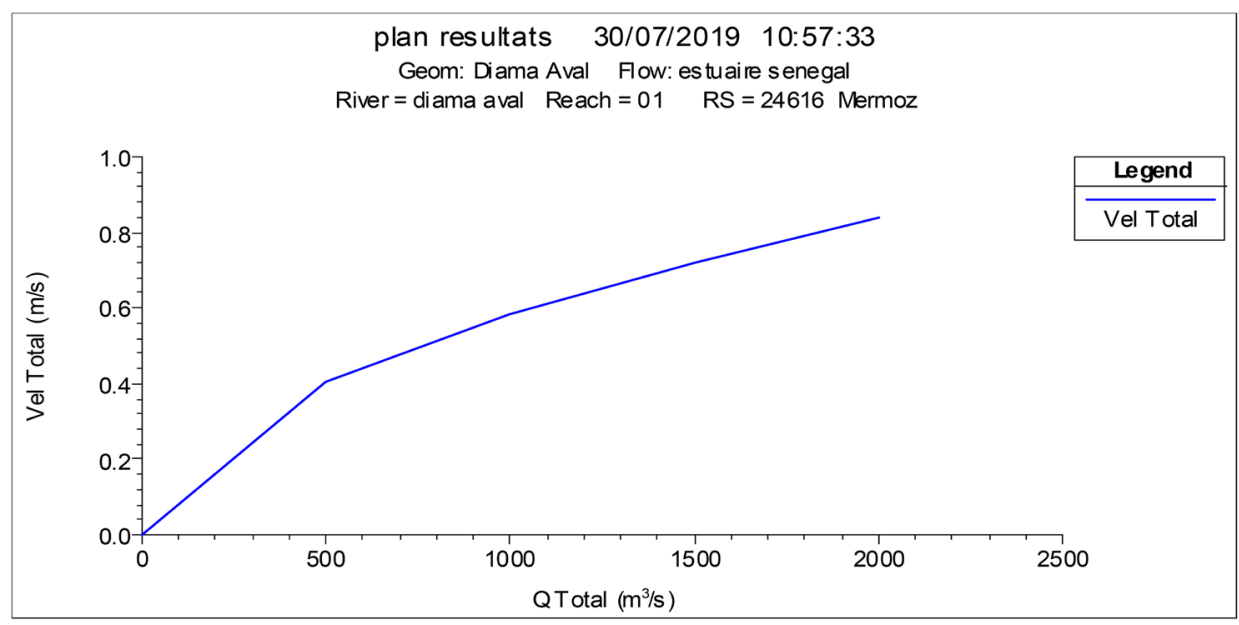

Station 3: Mermoz

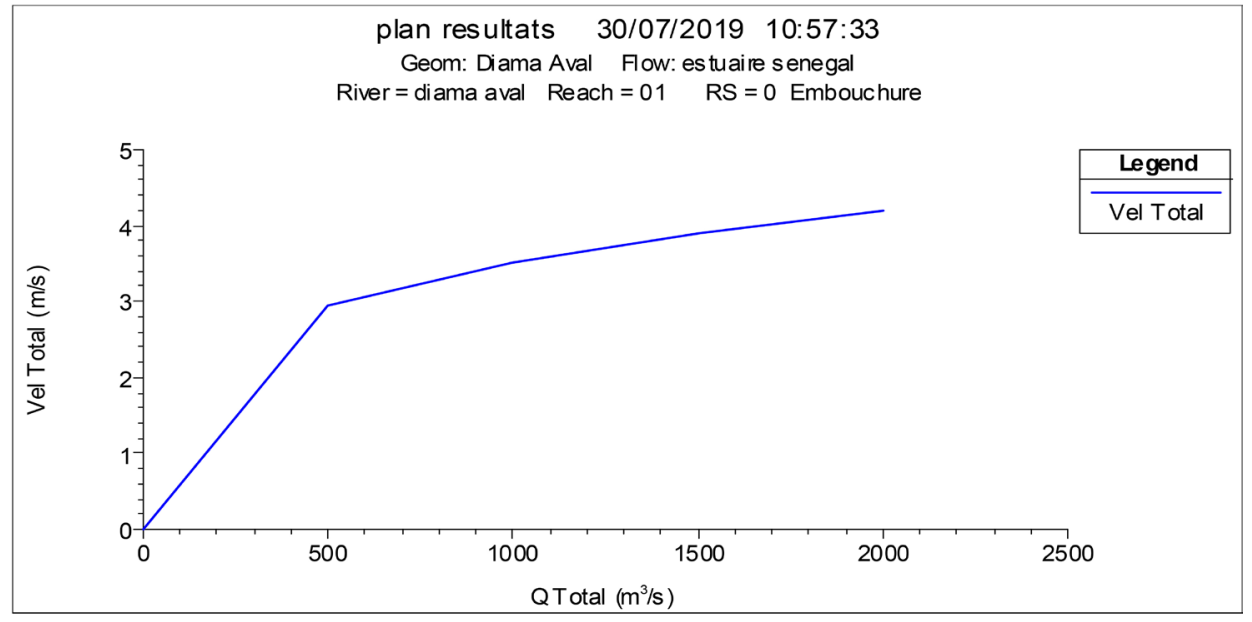

Station 4: Mouth

Figure 12. Variation of the flow velocity as a function of the flow rate.

Zone B: This is the area around the Faidherbe Bridge. This area contains the city of Saint Louis. For the same flows, the simulation shows a sharp increase in the water level (about $4.5 \mathrm{~m}$ ) in this area causing a flood (Figure 8). In this part of the canal, where the ground is not very permeable, the canal watercourse changes shape and seems narrower with limited vegetation on the banks.

In this area, the main channel has a depth of about $8 \mathrm{~m}$ at Mermoz and $10 \mathrm{~m}$ at the Faidherbe Bridge. At the Faidherbe Bridge, the velocities are approximately $0.4 \mathrm{~m} / \mathrm{s}$ and $1 \mathrm{~m} / \mathrm{s}$ for flow rates of $500 \mathrm{~m}^{3} / \mathrm{s}$ and $2000 \mathrm{~m}^{3} / \mathrm{s}$ respectively and the variation of the water height between these flows is $2 \mathrm{~m}$ (Figure 11).

Zone C: This zone is located between the Faidherbe bridge and the mouth (Figure 9). This area is connected to the outlet of the river by a floodwater drainage canal. Indeed, since October 3, 2003 a new point of communication river-ocean is created by the opening, on the "Langue de Barbarie", a relief channel located $7 \mathrm{~km}$ downstream of the city of Saint-Louis. This book was intended to save the city of Saint-Louis floodwaters that threatened to flood. Since its opening, the canal has continued to expand under the combined effects of swell and coastal drift and has increased from $4 \mathrm{~m}$ in October 2003 at $5 \mathrm{~km}$ today. 


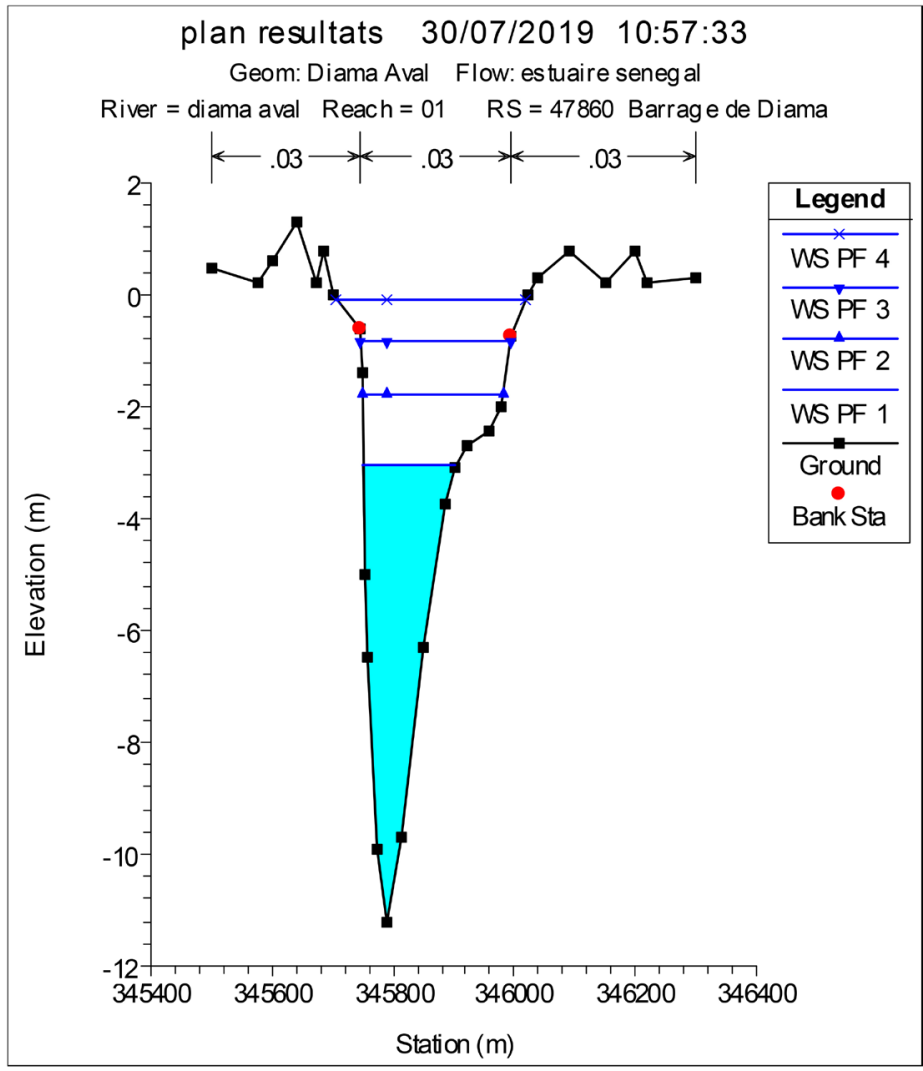

Station 1: Diama Dam

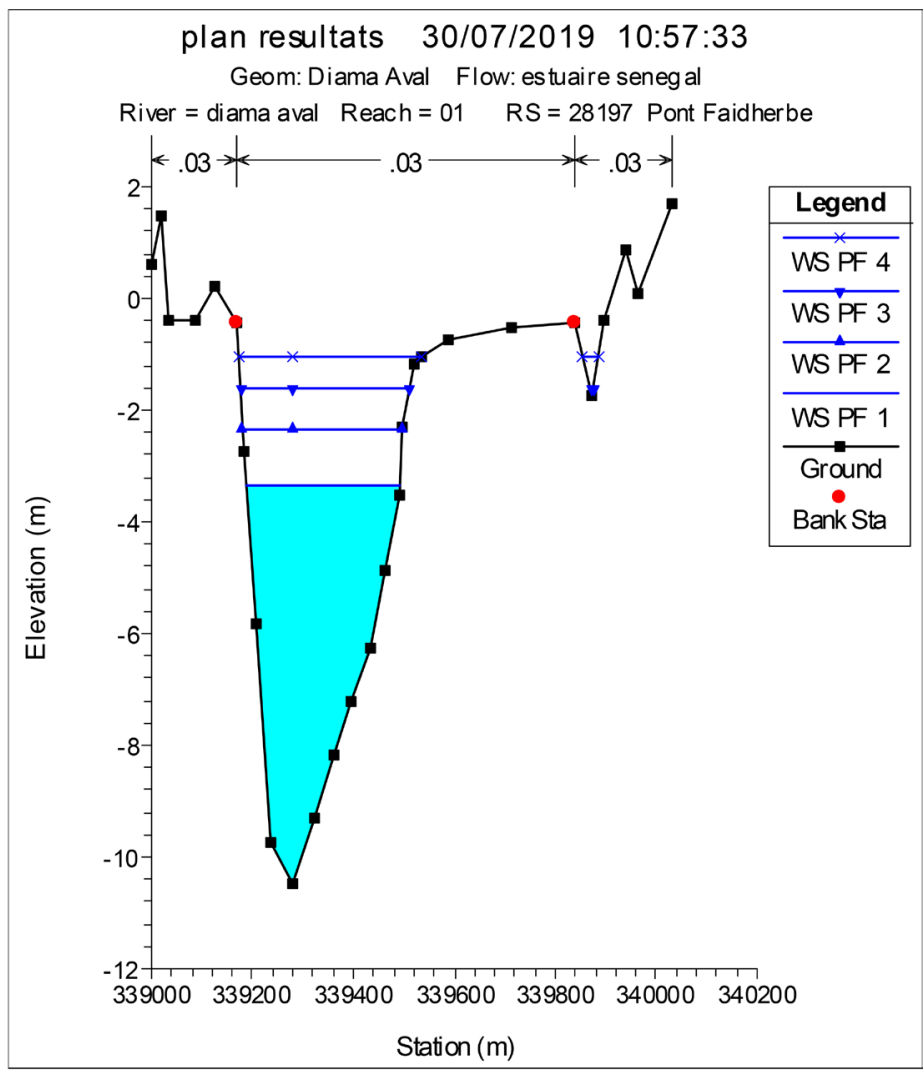

Station 2: Faidherbe Bridge 


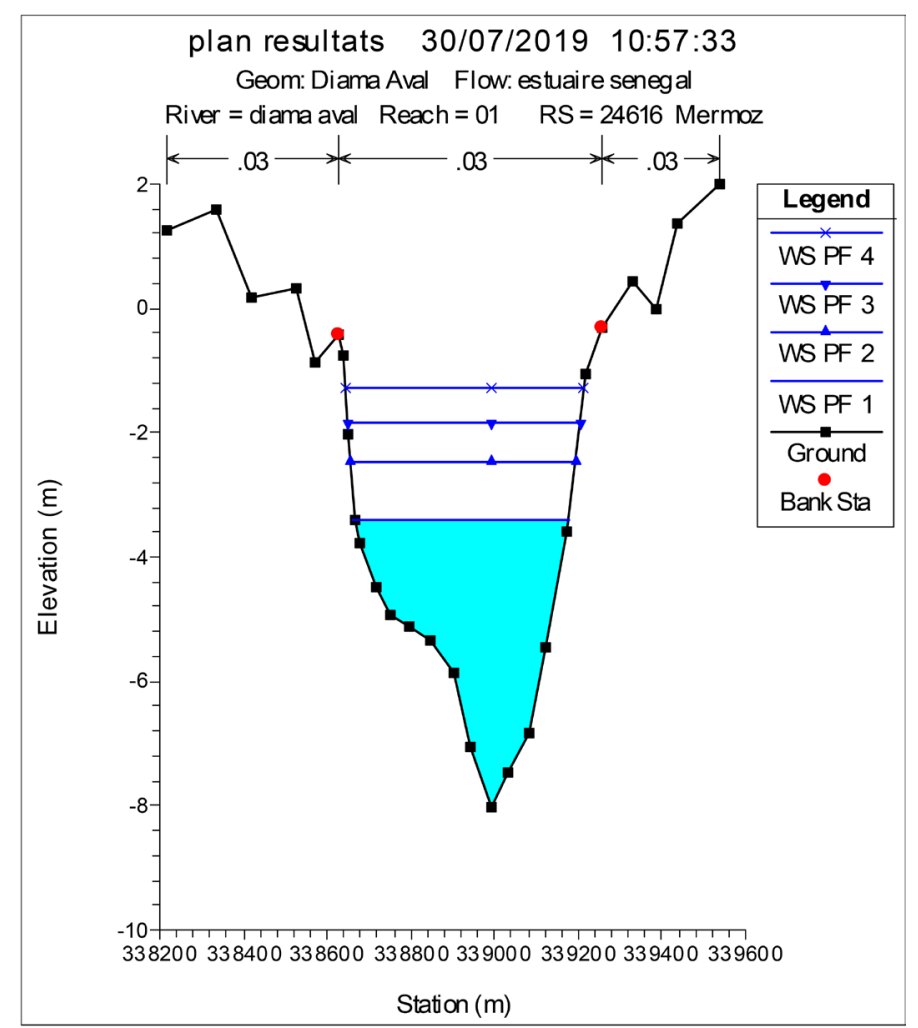

Station 3: Mermoz

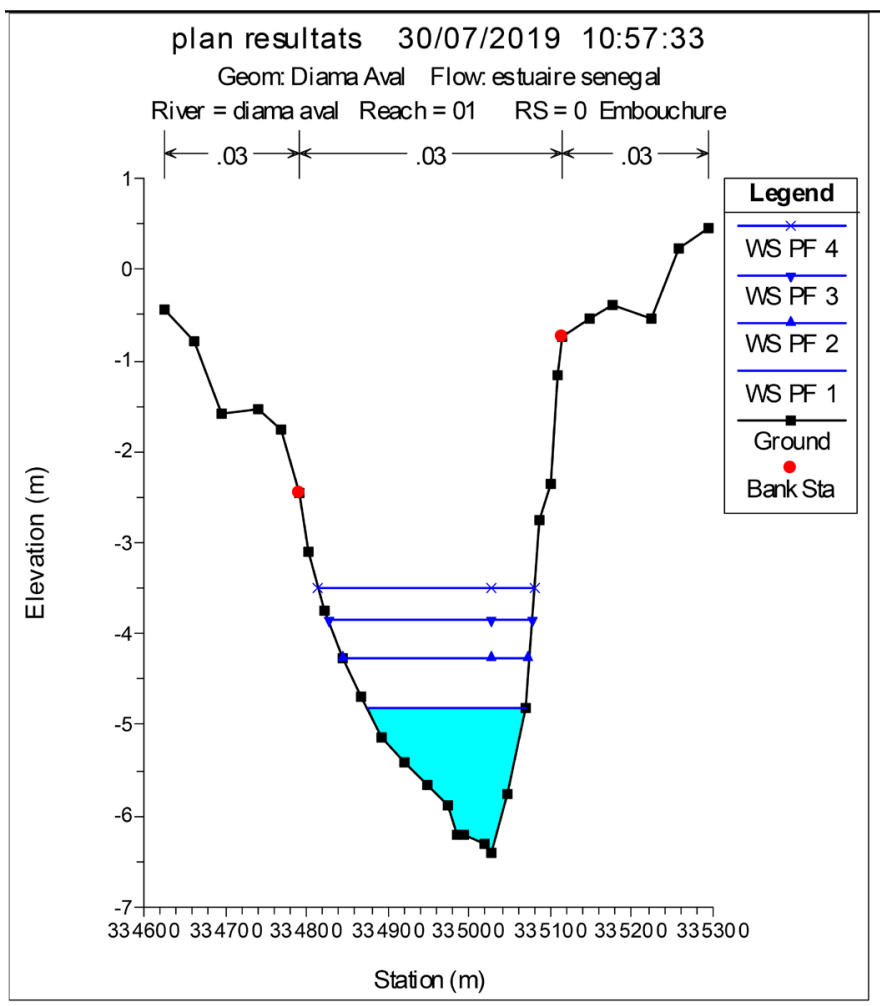

Station 4: Mouth

Figure 13. Representation of the water level modeling (WS) on the profiles of the four stations for four different flows: PF1 $500 \mathrm{~m}^{3} / \mathrm{s}$, PF2 $1000 \mathrm{~m}^{3} / \mathrm{s}$, PF $31500 \mathrm{~m}^{3} / \mathrm{s}$ and PF4 $2000 \mathrm{~m}^{3} / \mathrm{s}$. 


\section{Conclusions}

River flow modeling software is sophisticated and increasingly used in natural risk management and mapping by delineating risk areas. The overall results made it possible to locate the flood zones, the speeds, the water heights, etc. These results are reliable and consistent with the morphology of the estuary. The study area has undergone a profound restructuring over the last twenty years. In parallel with increasing awareness of the problem of floods, bridges, dams and rehabilitations of the river and its tributaries have been built. However, only a drop of water at the Diama dam with a flow of $2000 \mathrm{~m}^{3} / \mathrm{s}$ is required for the water level to increase by $3 \mathrm{~m}$ at Diama, $2 \mathrm{~m}$ at the Faidherbe Bridge and $1.3 \mathrm{~m}$ at the mouth causing flooding of the streets and neighborhoods of the city of Saint-Louis. We also find that the flow velocities also depend on the flow rates of water releases at the Diama dam. For a peak discharge of $2000 \mathrm{~m}^{3} / \mathrm{s}$, the flow velocity of the flood is $1.52 \mathrm{~m} / \mathrm{s}$ at Diama, $1 \mathrm{~m} / \mathrm{s}$ at Faidherbe Bridge and $4.2 \mathrm{~m} / \mathrm{s}$ at the mouth. Moreover, this very high speed at the mouth is one of the main causes of fishing pirogue accidents noted in this area since the opening of the unloading channel (new mouth).

To manage flood situations during water releases at the Diama dam, real-time water level monitoring and measurement equipment should be installed upstream of the dam. This model could then be used as a decision tool by the public authorities. It is also important to take into account the storage areas to the left and right of the Diama dam and the development plan simulator to propose for flood protection in the city of Saint Louis.

\section{Conflicts of Interest}

The authors declare no conflicts of interest regarding the publication of this paper.

\section{References}

[1] Kane, C. (2010) Vulnerability of the Socio-Environmental System in the Sahel Region: The Example of the Senegal River Estuary. From Perception to Natural Risk Management. Doctoral Thesis, University of Strasbourg, Strasbourg, 318 p.

[2] Ndiaye, A. (2004) Fluvial Dynamics and Morphosedimentary Evolution of the Senegal River Estuary after the Impoundment of the Diama Dam. Doctoral Thesis, Cheikh Anta DIOP University of Dakar, Dakar, 149 p.

[3] Yang, J., Townsend, R.D. and Daneshfar, B. (2006) Applying the HEC-RAS Model and GIS Techniques in River Network Floodplain Delineation. Canadian Journal of Civil Engineering, 33, 19-28. https://doi.org/10.1139/105-102

[4] Moya Quiroga, V., Kurea, S., Udoa, K. and Manoa, A. (2016) Application of 2D Numerical Simulation for the Analysis of the February 2014 Bolivian Amazonia Flood: Application of the New HEC-RAS Version 5. Revista Iberoamericana del Agua, 3, 25-33. https://doi.org/10.1016/j.riba.2015.12.001

[5] US Army Corps of Engineers, Hydrologic Engineering Center (2016) HEC-RAS. River Analysis System-Hydraulic User's Manual. 
[6] Tate, E.C., Maidment, D.R., Olivera, F. and Anderson, D.J. (2002) Creating a Terrain Model for Floodplain Mapping. Journal of Hydrologic Engineering, 7, 100-108. https://doi.org/10.1061/(ASCE)1084-0699(2002)7:2(100)

[7] Patro, S., Chatterjee, S., Singh, R. and Raghuwanshi, N.S. (2009) Flood Inundation Modeling Using MIKE FLOOD and Remote Sensing Data. Journal of the Indian Society of Remote Sensing, 37, 107-118. https://doi.org/10.1007/s12524-009-0002-1

[8] Karamouz, M., Zahmatkesh, Z., Goharian, E., Goharian, E. and Nazif, S. (2014) Combined Impact of Inland and Coastal Floods: Mapping Knowledge Base for Development of Planning Strategies. Journal of Water Resources Planning and Management, 141, No. 8. https://doi.org/10.1061/(ASCE)WR.1943-5452.0000497

[9] Soualmia, A. and Gharbi, M. (2014) Tests of Simulated Floods in the Medjerda Watershed (Tunisia). Lebanese Science Journal, 15, no.2.

[10] Nut, N. and Plermkamon, V. (2015) Floodplain Mapping Using HEC-RAS and GIS in Nam Phong River Basin, Thailand. International Journal of Environmental and Rural Development, 6.

[11] Patel, C.G. and Gundaliya, P.J. (2016) Floodplain Delineation Using HECRAS Model-A Case Study of Surat City. Open Journal of Modern Hydrology, 6, 34-42. https://doi.org/10.4236/ojmh.2016.61004

[12] Khattak, M.S., Anwar, F., Saeed, T.U., Sharif, M., Sheraz, K. and Ahmed, A. (2016) Floodplain Mapping Using HEC-RAS and ArcGIS: A Case Study of Kabul River. Arabian Journal of Geosciences, 41, 1375-1390. https://doi.org/10.1007/s13369-015-1915-3

[13] Hammerling, M., Walczak, N., Walczak, Z. and Zawadzki, P. (2016) The Possibilities of Using HEC-RAS Software for Modeling Hydraulic Conditions of Water Flow in the Fish Pass Exampled by the Pomilowo Barrage on the Wieptza River. Journal of Ecological Engineering, 17, 81-89. https://doi.org/10.12911/22998993/62294

[14] Hakim, F.A., Akhtar, A., Sultan, B. and Shabir, A. (2016) One Dimensional Steady Flow Analysis Using HECRAS: A Case of River Jhelum, Jammu and Kashmir. European Scientific Journal, 12, 340-350. https://doi.org/10.19044/esj.2016.v12n32p340

[15] Azouagh, A., El Bardai, R., Hilal, I. and Stitou el Messari, J. (2018) Integration of GIS and HEC-RAS in Floods Modeling of Martil River (Northern Morocco). European Scientific Journal Edition, 14. https://doi.org/10.19044/esj.2018.v14n12p130

[16] Prata, D., Marins, M., Sobral, B., Conceição, A. and Vissirini, F. (2011) Flooding Analysis, Using HEC-RAS Modeling for Taquaraçuriver, in the Ibiraçu City, Espírito Santo, Brazil. 12nd International Conference on Urban Drainage, Porto Alegre/Brazil, 11-16.

[17] Hirtan, R.-I. (2015) Floodplain Delineation for Calnau River Using HEC-RAS Software. Scientific Papers. Series E. Land Reclamation, Earth Observation \& Surveying, Environmental Engineering, Volume 4.

[18] Ullah, S., Farooq, M., Sarwar, T., Tareen, M.J. and Wahid, M.A. (2016) Flood Modeling and Simulations Using Hydrodynamic Model and ASTER DEM: A Case Study of Kalpani River. Arabian Journal of Geosciences, 9, 439. https://doi.org/10.1007/s12517-016-2457-Z

[19] Lahsaini, M. and Tabyaoui, H. (2018) Mono Dimensional Hydraulic Modeling By HEC RAS, Application on L'oued Aggay (City of Sefrou). European Scientific Journal Edition, 14, 110. https://doi.org/10.19044/esj.2018.v14n18p110

[20] Shayannejad, M., Ostad-Ali-Askari, K., Eslamian, S., Singh, V.P. and Dalezios, N.R. (2018) Analyzing of Flow in Open Channels Networks Using HEC-RAS. Natural Resources Journal, 2, 1-7. https://doi.org/10.23880/JENR-16000136 
[21] Ezza, H. (2018) Integrating GIS and HEC-RAS to Model Assiut Plateau Runoff. The Egyptian Journal of Remote Sensing and Space Sciences, 21, 219-227. https://doi.org/10.1016/j.ejrs.2017.11.002

[22] Yang, S.-H., Pan, Y.-W., Dong, J.-J., Yeh, K.-C. and Liao, J.-J. (2013) A Systematic Approach for the Assessment of Flooding Hazard and Risk Associated with a Landslide Dam. Natural Hazards, 65, 41-62. https://doi.org/10.1007/s11069-012-0344-9

[23] Husain, A. (2017) Flood Modelling by Using HEC-RAS. International Journal of Engineering Trends and Technology, 50, 6. https://doi.org/10.14445/22315381/IJETT-V50P201

[24] Timbadiya, P.V., Lal Patel, P. and Porey, P.D. (2011) Calibration of HEC-RAS Model on Prediction of Flood for Lower Tapi River, India. Journal of Water Resource and Protection, 3, 805-811. https://doi.org/10.4236/jwarp.2011.311090

[25] Kane, S., Sambou, S., Leye, I., Diedhiou, R., Tamba, S., Cisse, M.T., Ndione, D.M. and Sane, M.L. (2017) Modeling of Unsteady Flow through Junction in Rectangular Channels: Impact of Model Junction in the Downstream Channel Hydrograph. Computational Water, Energy, and Environmental Engineering, 6, 304-319.

https://doi.org/10.4236/cweee.2017.63020

[26] Yadav, V.G., Mehta, D. and Waikhom, S. (2015) Simulation of HEC-RAS model on Prediction of Flood for Lower Tapi River Basin, Surat. Journal of Emerging Technologies and Innovative Research, 2, 105-112.

[27] Bourak, A., Midaoui, A., Lahrach, A., Elarrim, A. and Chaouni, A.A. (2017) Hydraulic Modeling of the Sebou-Fouarat System, City of Kenitra, Morocco-Case of the 2010 Floods. European Scientific Journal Edition, 13, 368.

https://doi.org/10.19044/esj.2017.v13n12p368 